\title{
Hubungan Antara Status Gizi, Usia Menarche dengan Kejadian Dysmenorrhea Primer pada Remaja Putri di SMPN 3 Jember
}

\section{(The Correlation between Nutritional Status, Age of Menarche and the Case of Primary Dysmenorrhea in Female Students at SMPN 3 Jember)}

\author{
Afthon IIman Huda ${ }^{1}$, Farida Wahyu Ningtyias ${ }^{2}$, Sulistiyani ${ }^{3}$ \\ Bagian Gizi Kesehatan Masyarakat \\ Fakultas Kesehatan Masyarakat Universitas Jember \\ JI. Kalimantan I No.93, Sumbersari, Kabupaten Jember, Jawa Timur 68121 e- \\ mail korespondensi : farida.fkm@unej.ac.id
}

\begin{abstract}
Primary dysmenorrhea is a problem with menstrual disorders, symptom such as cramps in the lower abdomen spreading to the back or legs. It occurs in the first year or more after menstruation; and can be felt in the first 24 hours of menstruation and even lasts up to 48-72 hours. Young women who have abnormal nutritional status and early menarche age may get an impact to the primary dysmenorrhea. This study aimed to analyze the relationship between nutritional status, age of menarche, and primary dysmenorrhea in female students in SMPN 3 Jember. This study was an observational analytic study using a cross sectional approach. The research population was 445 people with a sample of 82 people. The results of statistical tests showed that there was a relationship between nutritional status and age of menarche $(p=0,000)$, nutritional status and primary dysmenorrhea $(p=0.042)$, age of menarche and primary dysmenorrhea $(p=0.001)$ and there was no relationship between physical activity and primary dysmenorrhea $(p=0.913)$.
\end{abstract}

Keywords: Nutritional Status, Age of Menarche, Primary dysmenorrhea

\begin{abstract}
Abstrak
Dysmenorrhea primer merupakan masalah gangguan menstruasi seperti kram dibagian bawah perut yang menjalar ke punggung atau kaki dan terjadi pada tahun pertama atau lebih setelah mengalami menstruasi dan dapat dirasakan pada 24 jam pertama menstruasi dan dapat bertahan sampai 48-72 jam. Remaja wanita yang mempunyai status gizi tidak normal dan usia menarche dini akan berdampak pada kejadian dysmenorrhea primer. Penelitian ini bertujuan untuk menganalisis Hubungan Antara Status Gizi, Usia Menarche dengan Kejadian Dysmenorrhea Primer pada Remaja Putri di SMPN 3 Jember. Penelitian ini merupakan penelitian analitik observasional dengan menggunakan pendekatan cross sectional. Populasi penelitian sebanyak 445 orang dengan sampel sebanyak 82 orang. Hasil uji statistic menunjukkan terdapat hubungan antara status gizi dengan usia menarche $(p=0,000)$, terdapat hubungan antara status gizi dengan dysmenorrhea primer $(p=0,042)$ dan tidak terdapat hubungan antara aktivitas fisik dengan dysmenorrhea primer $(p=0,913)$.
\end{abstract}

Kata Kunci: Status Gizi, Usia Menarche, Dysmenorrhea Primer 


\section{Pendahuluan}

Dysmenorrhea primer merupakan masalah gangguan menstruasi seperti kram dibagian bawah perut yang menjalar ke punggung atau kaki [1] dan terjadi pada tahun pertama atau lebih setelah mengalami menarche [2] dan dapat dirasakan pada 24 jam pertama menstruasi dan dapat bertahan sampai 48-72 jam [3]. Dysmenorrhea primer merupakan sakit nyeri pada menstruasi tanpa adanya kelainan yang nyata pada alat-alat genital [4] Perempuan yang sedang haid sering kali disertai dengan berbagai gangguan haid. Seperti, mengalami kram karena kontraksi otot - otot halus pada rahim, sakit kepala, sakit perut, gelisah berlebihan, merasa letih dan lemas, depresi hingga nyeri haid

(dysmenorrhea) yang luar biasa yang dapat mengganggu aktivitas sehari - hari [5].

$$
\text { Faktor yang mempengaruhi }
$$

dysmenorrhea primer antara lain: usia menarche, status gizi, aktivitas fisik [6] riwayat keluarga, lama menstruasi dan panjang siklus menstruasi [3]. Status gizi yang tidak normal (underweight dan overweight) dapat juga mengakibatkan nyeri pada saat menstruasi (dysmenorrhea) karena hiperplasi pembuluh darah pada organ reproduksi wanita [7]. Status gizi overweight terjadi karena penimbunan jaringan lemak secara berlebihan akibat dari asupan energi dan pemakaian energi yang tidak seimbang atau kurangnya aktivitas fisik. Namun disisi lain underweight ternyata juga dapat mengalami dysmenorrhea primer. Usia menarche dini juga menjadi faktor risiko tejadinya dysmenorrhea primer, karena usia menarche yang lebih awal memicu terjadinya siklus ovulasi yang lebih awal juga sehingga kemungkinan terjadi dysmenorrhea yang awal juga. Setelah terjadinya ovulasi, apabila tidak terjadi pembuahan maka sel folikel yang sudah tua akan mengalami atresia. Hal ini akan diikuti penurunan kadar estrogen dan progesteron yang merangsang prostaglandin untuk keluar. Prostaglandin ini menyebabkan vasokontriksi pembuluh darah yang memicu dysmenorrhea [8]. Dysmenorrhea akan meningkat pada wanita yang mengkonsumsi kopi, perokok, peminum alkohol, tidak aktif secara seksual dan belum pernah melahirkan [9].

e-Journal Pustaka Kesehatan, vol. 8 (no. 2), Mei, 2020
Berdasarkan PIK-KRR (Pusat Informasi dan Konseling Kesehatan Reproduksi Remaja) di Indonesia tahun 2009 angka kejadian dysmenorrhea terdiri dari $72,89 \%$ dysmenorrhea primer dan $27,11 \%$ dysmenorrhea sekunder dan angka kejadian dysmenorrhea berkisar 45-95\% dikalangan perempuan usia produktif [10]. Berdasarkan data dari [11] kasus tertinggi gangguan mestruasi pada remaja siswi sekolah umur 1014 tahun sebanyak 1457 kasus, daerah

Sumbersari menempati urutan pertama dengan 740 kasus, Ledokombo 122 kasus, Tanggul 116 kasus, Sumberbaru 109 kasus, Ajung 63 kasus.

Dampak yang ditimbulkan karena rasa nyeri yang dirasakan kadang teramat sakit dan mengganggu aktivitas sehari-hari, aktivitas belajar dan konsentrasi belajar mereka menurun [12]. Berdasarkan latar belakang diatas, maka peneliti tertarik melakukan penelitian di SMPN 3 Jember. Pemilihan lokasi ini dikarenakan SMPN 3 Jember merupakan salah satu SMP dengan jumlah siswi terbanyak se Kecamatan Sumbersari Kabupaten Jember.

\section{Metode Penelitian}

Penelitian ini bersifat analitik observasional dengan pendekatan kuantitatif yang tujuannya untuk mencari hubungan antara variabel yang lain [13]. Metode penelitian yang digunakan yaitu cross sectional, dimana variabel independen dan dependen di ukur pada waktu yang bersamaan [14]. Penelitian ini dilakukan di SMPN 3 Jember dengan populasi remaja siswi sebanyak 445 orang. Sampel pada penelitian ini sebanyak 82 orang dan telah memenuhi kriteria inklusi dan eksklusi. Besar sampel dalam penelitian ini di tentukan dengan rumus Slovin, dan teknik pengambilan sampel dilakukan dengan metode proportionate stratified random sampling. Variabel yang diteliti meliputi karakteristik usia responden, lama menstruasi, lama siklus menstruasi, tingkat aktivitas fisik, riwayat keluarga, status gizi, usia menarche dan status dysmenorrhea primer.

Data primer diperoleh melalui hasil wawancara dan pengukuran IMT/U menggunakan kuesioner dengan responden, sedangkan data sekunder diperoleh melalui pengambilan data dari instansi terkait. Data yang diperoleh dianalisis secara statistic 
Huda et al, Hubungan Status Gizi, Usia Menarche dengan Kejadian Dysmenorrhea Primer...

menggunakan chi square dan ditampilkan dalam bentuk tabel dan narasi.

\section{Hasil Penelitian}

\section{Gambaran Karakteristik Usia Responden}

Tabel 1. Distribusi Usia Responden

\begin{tabular}{lcc}
\hline Karakteristik usia & $\mathbf{n}$ & $\%$ \\
\hline 12 & 3 & 3,6 \\
13 & 21 & 25,6 \\
14 & 26 & 31,8 \\
15 & 29 & 35,4 \\
16 & 3 & 3,6 \\
\hline Total & $\mathbf{8 2}$ & $\mathbf{1 0 0}$ \\
\hline
\end{tabular}

Berdasarkan Tabel 1 dapat diketahui distribusi kelompok usia responden sebagian besar berada dalam usia 15 tahun sebanyak 29 responden $(35,4 \%)$ dan paling sedikit berada dalam usia 12 dan 16 tahun sebanyak 3 responden (3,6\%).

\section{Gambaran Lama Menstruasi}

Tabel 2. Distribusi Lama Menstruasi

\begin{tabular}{|c|c|c|}
\hline $\begin{array}{l}\text { Lama } \\
\text { Menstruasi }\end{array}$ & $\mathrm{n}$ & $\%$ \\
\hline Normal & 61 & 74,4 \\
\hline Tidak Normal & 21 & 25,6 \\
\hline Total & 82 & 100 \\
\hline
\end{tabular}

\section{Gambaran Lama Siklus Menstruasi}

Tabel 3. Distribusi Lama Siklus Menstruasi

\begin{tabular}{lcc}
\hline $\begin{array}{l}\text { Lama Siklus } \\
\text { Menstruasi }\end{array}$ & $\mathbf{n}$ & $\%$ \\
\hline Teratur & 62 & 75,6 \\
Tidak Teratur & 20 & 24,4 \\
\hline Total & $\mathbf{8 2}$ & $\mathbf{1 0 0}$ \\
\hline
\end{tabular}
Berdasarkan Tabel 3, sebagian besar sebanyak 62 responden $(75,6 \%)$ mengalami lama siklus menstruasi yang teratur berkisar 2135 hari.

\section{Gambaran Aktivitas Fisik}

Tabel 4. Distribusi Aktivitas Fisik

\begin{tabular}{lcc}
\hline Aktivitas Fisik & $\mathbf{n}$ & $\%$ \\
\hline Ringan & 79 & 96,3 \\
Sedang & 3 & 3,7 \\
\hline Total & $\mathbf{8 2}$ & $\mathbf{1 0 0}$ \\
\hline
\end{tabular}

e-Journal Pustaka Kesehatan, vol. 8 (no. 2), Mei, 2020
Berdasarkan Tabel 4, mayoritas responden mempunyai tingkat aktivitas fisik dengan kategori ringan (96,3\%).

\section{Gambaran Riwayat Keluarga}

Tabel 5. Distribusi Riwayat Kluarga

\begin{tabular}{lcc}
\hline $\begin{array}{l}\text { Riwayat } \\
\text { Keluarga }\end{array}$ & $\mathbf{n}$ & $\%$ \\
\hline Ada & 43 & 52,4 \\
Tidak & 39 & 47,6 \\
\hline Total & $\mathbf{8 2}$ & $\mathbf{1 0 0}$ \\
\hline \multicolumn{3}{c}{$\begin{array}{c}\text { Berdasarkan Tabel 5 dapat dilihat } \\
\text { bahwa 43 responden }\end{array}$} \\
$\begin{array}{l}\text { (52,4\%) } \\
\text { riwayat keluarga }\end{array}$ yang & mengailami \\
dysmenorrhea primer. & &
\end{tabular}

Gambaran Status Gizi

Tabel 6. Distribusi Status Gizi

\begin{tabular}{|c|c|c|}
\hline Status & $\mathbf{n}$ & $\%$ \\
\hline Kurus & 17 & 20,7 \\
\hline Normal & 48 & 58,5 \\
\hline Gemuk & 14 & 17,1 \\
\hline Obesitas & 3 & 3,7 \\
\hline Total & 82 & 100 \\
\hline $\begin{array}{l}\text { Berdas } \\
\text { reponden } \\
\text { besar sebanyak } \\
\text { status gizi norma }\end{array}$ & $\begin{array}{l}\text { Tabe } \\
\text { njukk } \\
\text { onde }\end{array}$ & $\begin{array}{l}\text { i statu } \\
\text { ian } \\
\text { mpuy }\end{array}$ \\
\hline
\end{tabular}

\section{Gambaran Usia Menarche}

Tabel 7. Distribusi Usia Menarche

\begin{tabular}{lll}
\hline Usia Menarche & $\mathbf{n}$ & $\%$ \\
\hline Normal & 57 & 69,5 \\
Cepat & 25 & 30,5 \\
\hline Total & $\mathbf{8 2}$ & $\mathbf{1 0 0}$ \\
\hline \multicolumn{3}{c}{ Berdasarkan Tabel 7, menunjukkan usia } \\
menarche responden dalam kategori normal \\
sebanyak 57 responden (69,5\%).
\end{tabular}

\section{Gambaran Dysmenorrhea Primer}

Tabel 8. Distribusi Dysmenorrhea Primer

\begin{tabular}{|c|c|c|}
\hline Dysmenorrhea Primer & $\mathbf{n}$ & $\%$ \\
\hline Iya & 57 & 69,5 \\
\hline Tidak & 25 & 30,5 \\
\hline Total & 82 & 100 \\
\hline
\end{tabular}
mayoritas responden mengalami dysmenorrhea primer sebanyak 57 responden (69,5\%). 
Huda et al, Hubungan Status Gizi, Usia Menarche dengan Kejadian Dysmenorrhea Primer...

\section{Hubungan antara Status Gizi dengan Usia Menarche}

Tabel 9. Hubungan antara Status Gizi dengan Usia Menarche

\begin{tabular}{|c|c|c|c|c|c|c|c|}
\hline \multirow{3}{*}{$\begin{array}{c}\text { Status } \\
\text { gizi }\end{array}$} & \multicolumn{4}{|c|}{ Usia Menarche } & \multicolumn{2}{|c|}{ Total } & \multirow{2}{*}{$\begin{array}{l}\text { P- } \\
\text { va } \\
\text { lu } \\
\text { e }\end{array}$} \\
\hline & \multicolumn{2}{|c|}{ Normal } & \multicolumn{2}{|c|}{ Cepat } & & & \\
\hline & $\mathbf{n}$ & $\%$ & $n$ & $\%$ & $\mathbf{n}$ & $\%$ & \\
\hline Kurus & 16 & 94,1 & 1 & 5,9 & 17 & 100 & \\
\hline Normal & 37 & 77,1 & 11 & 22,9 & 48 & 100 & \\
\hline $\begin{array}{l}\text { Gemuk } \\
\text { dan } \\
\text { obesitas }\end{array}$ & 4 & 23,5 & 13 & 76,5 & 17 & 100 & 0 \\
\hline Total & 57 & 69,5 & 25 & 30,5 & 82 & 100 & \\
\hline
\end{tabular}

Tabel 9 menunjukkan $p$-value $<0,05$ yang berarti terdapat hubungan antara status gizi dengan usia menarche.

\section{Hubungan antara Status Gizi dengan Dysmenorrhea Primer}

Tabel 10. Hubungan antara Status Gizi dengan Dysmenorrhea Primer

\begin{tabular}{|c|c|c|c|c|c|c|c|}
\hline \multirow{3}{*}{$\begin{array}{l}\text { Status } \\
\text { gizi }\end{array}$} & \multicolumn{4}{|c|}{$\begin{array}{c}\text { Dysmenorrhea } \\
\text { Primer }\end{array}$} & \multirow{2}{*}{\multicolumn{2}{|c|}{ Total }} & \multirow{2}{*}{$\begin{array}{c}\text { P. } \\
\text { valu } \\
\mathbf{e}\end{array}$} \\
\hline & \multicolumn{2}{|c|}{ Ya } & \multicolumn{2}{|c|}{ Tidak } & & & \\
\hline & $\mathrm{n}$ & $\%$ & $\mathrm{n}$ & $\%$ & $\mathrm{n}$ & $\%$ & \\
\hline Kurus & 10 & 58,8 & 7 & 41,2 & 17 & 100 & \\
\hline Normal & 31 & 64,6 & 17 & 35,4 & 48 & 100 & \\
\hline $\begin{array}{l}\text { Gemuk } \\
\text { dan } \\
\text { obesitas }\end{array}$ & 16 & 94,1 & 1 & 5,9 & 17 & 100 & 0,042 \\
\hline Total & 57 & 69,5 & 25 & 30,5 & 82 & 100 & \\
\hline
\end{tabular}

Tabel 10 menunjukkan $p$-value $<0,05$ yang berarti bahwa terdapat hubungan antara status gizi dengan dysmenorrhea primer.

\section{Hubungan antara Usia Menarche dengan Dysmenorrhea Primer}

Tabel 11. Hubungan antara Usia Menarche dengan Dysmenorrhea Primer

\begin{tabular}{|c|c|c|c|c|c|c|c|}
\hline \multirow{3}{*}{$\begin{array}{c}\text { Usia } \\
\text { Menarch } \\
e\end{array}$} & \multicolumn{4}{|c|}{$\begin{array}{c}\text { Dysmenorrhea } \\
\text { Primer }\end{array}$} & \multirow{2}{*}{\multicolumn{2}{|c|}{ Total }} & \multirow{2}{*}{$\begin{array}{c}\text { P- } \\
\text { valu } \\
\text { e }\end{array}$} \\
\hline & \multicolumn{2}{|c|}{ Ya } & \multicolumn{2}{|c|}{ Tidak } & & & \\
\hline & $\mathrm{n}$ & $\%$ & $\mathrm{n}$ & $\%$ & $n$ & $\%$ & \multirow{4}{*}{0,042} \\
\hline Normal & 33 & 57,9 & 24 & 42,1 & 57 & 100 & \\
\hline Cepat & 24 & 96 & 1 & 4 & 25 & 100 & \\
\hline Total & 64 & 69,5 & 25 & 30,5 & 82 & 100 & \\
\hline
\end{tabular}

Berdasarkan Tabel 11 menunjukkan pvalue < 0,05 yang berarti bahwa terdapat hubungan

e-Journal Pustaka Kesehatan, vol. 8 (no. 2), Mei, 2020 antara usia menarche dengan dysmenorrhea primer.

\section{Hubungan antara Aktivitas Fisik dengan Dysmenorrhea Primer}

Tabel 12. Hubungan antara Aktivitas Fisik dengan Dysmenorrhea Primer

\begin{tabular}{llllllll}
\hline \multirow{2}{*}{$\begin{array}{c}\text { Aktivita } \\
\text { s Fisik }\end{array}$} & \multicolumn{4}{c}{$\begin{array}{c}\text { Dysmenorrhea } \\
\text { Primer }\end{array}$} & Total & \begin{tabular}{c} 
P- \\
valu \\
\cline { 2 - 6 }
\end{tabular} & \multicolumn{4}{c}{ Ya } & \multicolumn{2}{c}{ Tidak } & & & e \\
\cline { 2 - 7 } & $\mathrm{n}$ & $\%$ & $\mathrm{n}$ & $\%$ & $\mathrm{n}$ & $\%$ & \\
\hline Ringan & 55 & 67,1 & 24 & 29,3 & 79 & 100 & 0,913 \\
\hline Sedang & 2 & 2,4 & 1 & 1,2 & 3 & 100 & \\
\hline Total & 57 & 69,5 & 25 & 30,5 & 82 & 100 & \\
\hline
\end{tabular}

Tabel 12 menunjukkan hasil $p$-value keseluruhan yang diperoleh $>0,05$ yang berarti bahwa tidak terdapat hubungan antara aktivitas fisik dengan dysmenorrhea primer.

\section{Pembahasan}

Usia

Kejadian dysmenorrhea primer sangat dipengaruhi oleh usia wanita. Semakin tua umur seseorang, semakin sering ia mengalami menstruasi dan semakin lebar leher rahim maka sekresi hormon prostaglandin akan semakin berkurang. Hasil penelitian menunjukkan bahwa sebagian besar responden ber usia 15 tahun $(35,4 \%)$ dan paling sedikit pada usia 12 dan 16 tahun $(3,6 \%)$, dan rata-rata usia responden SMPN 3 Jember yaitu 14,09 tahun. Pada usia akhir 20 an atau awal 30 an dysmenorrhea primer nantinya akan hilang dengan makin menurunnya fungsi saraf rahim akibat penuaan [8].

\section{Lama Menstruasi}

Semakin lama menstruasi terjadi, maka semakin sering uterus berkontrakasi, akibatnya semakin banyak pula prostaglandin yang di keluarkan. Akibat tingginya produksi prostaglandin maka timbul rasa nyeri [8]. Hasil penelitian menunjukkan sebagian besar sebanyak 61 responden $(74, \%)$ mengalami lama menstruasi yang normal berkisar 2-7 hari, 3 responden mengalami lama menstruasi tidak normal $<2$ hari dan 18 responden mengalami lama menstruasi tidak normal $>7$ hari. Sejalan dengan penelitian yang dilakukan oleh [5] mengenai lama menstruasi pada SMA Dharma 
Huda et al, Hubungan Status Gizi, Usia Menarche dengan Kejadian Dysmenorrhea Primer...

Pancasila Medan terdapat 83 responden dengan lama menstruasi normal dan 11 responden dengan lama menstruasi tidak normal.

\section{Lama Siklus Menstruasi}

Apabila seorang perempuan dengan siklus haid yang lebih panjang (lebih dari 36 hari), rentan mengalami dysmenorrhea. Hal ini dikarenakan semakin lama siklus haid seorang perempuan maka produksi hormon prostaglandin akan meningkat. Hormon prostaglandin inilah yang dapat menyebabkan seorang perempuan mengalami rasa sakit ketika haid [15]. Hasil penelitian menunjukkan sebagian besar sebanyak 62 responden $(75,6 \%)$ mengalami lama siklus menstruasi yang teratur berkisar 2135 hari, 7 responden mengalami lama siklus menstruasi tidak teratur $<21$ hari dan 13 responden mengalami lama menstruasi tidak teratur $>35$ hari. Sejalan dengan penelitian yang dilakukan oleh [16] terdapat 76 responden dengan lama siklus menstruasi teratur dan 41 responden dengan lama siklus menstruasi tidak teratur.

\section{Aktivitas Fisik}

Aktivitas fisik yang dilakukan dengan teratur dapat meningkatkan kelenturan dan kekuatan otot. Kontraksi pada otot-otot rahim ketika peluruhan menstruasi rasa sakit akan terasa ringan karena otot-otot yang lentur dan kuat [17]. Hasil penelitian menunjukkan mayoritas responden mempunyai tingkat aktivitas fisik dengan kategori ringan (96,3\%) dan sisanya mempunyai tingkat aktivitas fisik dengan kategori sedang (3,7\%). Sejalan dengan penelitian yang diakukan oleh [18] pada remaja di SMPK Harapan Denpasar terdapat 75 responden dengan aktivitas fisik kategori rendah, 10 responden dengan aktivitas fisik kategori sedang, 12 responden dengan aktivitas fisik kategori berat.

\section{Riwayat Keluarga}

Kondisi anatomi dan fisiologis dari seseorang pada umumnya hampir sama dengan orang tua dan saudara - saudaranya [19]. Hasil penelitian menunjukkan 43 responden $(52,4 \%)$ mempunyai riwayat keluarga yang mengalami dysmenorrhea primer dan 39 responden $(47,6 \%)$ tidak mempunyai riwayat keluarga yang mengalami dysmenorrhea primer. Sejalan dengan penelitian yang dilakukan oleh [20] terdapat 61 responden mempunyai riwayat keluarga dysmenorrhea primer dan 29 responden tidak mempunyai riwayat keluarga dysmenorrhea primer.

\section{Status Gizi}

Status gizi remaja ditentukan dari keadaan tubuh remaja yang dihitung berdasarkan IMT/U yang kategorinya (sangat kurus, kurus, normal, gemuk dan obesitas) berdasarkan [21] tentang Standar Antropometri Penilaian Status Gizi Anak dan Remaja.Hasil penelitian menunjukkan status gizi reponden sebagian besar sebanyak 48 responden $(58,5 \%)$ mempuyai status gizi normal, dan sisanya mempunyai status gizi kurus, gemuk dan paling sedikit obesitas. Sejalan dengan penelitian yang dilakukan oleh [22] mengengenai status gizi remaja putri di MTs $\mathrm{N}$ Tangerang II Pamulang didapatkan sebanyak 92 orang $(76 \%)$ memiliki status gizi normal, 13 orang $(10,7 \%)$ memiliki status gizi gemuk, 14 orang $(11,6 \%)$ dengan status gizi obesitas dan 2 orang $(1,7 \%)$ dengan status gizi kurus.

\section{Usia Menarche}

Menarche merupakan menstruasi yang pertama kali dialami wanita, dimana secara fisik ditandai dengan keluarnya darah dari vagina akibat peluruhan lapisan endometrium. Hormon yang berpengaruh terhadap usia terjadinya menarche adalah estrogen dan progesterone [23]. Hasil penelitian menunjukkan usia menarche responden dalam kategori normal (1215 tahun) sebanyak 57 responden $(69,5 \%)$ dan usia menarche responden dalam kategori cepat ( $<12$ tahun) sebanyak 25 responden $(30,5 \%)$. Penelitian lain yang dilakukan oleh [24] didapatkan 96 siswi $(57,7 \%)$ mengalami usia menarche dini, 69 siswi $(41,5 \%)$ mengalami usia menarche normal, dan 1 siswi $(0,6 \%)$ mengalami usia menarche lambat. Penelitian lain yang dilakukan oleh [25] dari 88 responden yang mengalami mengalami usia menarche dini sebanyak 60 responden.

\section{Dysmenorrhea Primer}

Dysmenorrhea primer merupakan ketidaknyamanan fisik atau nyeri pada saat dan menjelang menstruasi dengan gejala yang kompleks berupa nyeri kram perut bagian bawah 
yang menjalar ke punggung atau kaki [1]. Hasil penelitian menunjukkan mayoritas responden mengalami dysmenorrhea primer sebanyak 57 responden $(69,5 \%)$ dan 25 responden $(30,5 \%)$ tidak mengalami dysmenorrhea primer. Dampak yang sering dirasakan responden ketika mengalami dysmenorrhea primer yaitu kurang konsentrasi mengikuti pelajaran di kelas dan jarang sekali responden absen sekolah. Hal ini sejalan dengan penelitian yang dilakukan oleh [26] terdapat 42 siswi $(68,9 \%)$ mengalami dysmenorrhea primer dan 19 siswi $(31,1 \%)$ tidak mengalami dysmenorrhea primer.

\section{Hubungan antara Status Gizi dengan Usia Menarche}

Status gizi underweight akan mengakibatkan menarche terlambat dari yang seharusnya dan status gizi overweight akan mengakibatkan menarche lebih dini [27].

Hasil analisis bivariat pada penelitian ini antara status gizi dengan usia menarche di dapatkan nilai $p$-value sebesar 0,000 atau lebih kecil dari $\alpha(0,05)$ maka dapat disimpulkan bahwa terdapat hubungan antara status gizi dengan usia menarche.

Hal ini sesuai dengan yang disebutkan [28] bahwa pada umumnya mereka yang menjadi matang lebih dini akan memiliki IMT yang lebih tinggi dan mereka yang matang terlambat memiliki IMT yang lebih kecil pada usia yang sama. Sejalan dengan penelitian yang dilakukan oleh [29] analisis chi-square menunjukan bahwa ada hubungan antara status gizi dengan kejadian menstruasi dini, dengan nilai signifikansi sebesar 0.046 atau $p<0,05$.

\section{Hubungan antara Status Gizi dengan Dysmenorrhea Primer}

Penelitian yang dilakukan [30] bahwa konsumsi lemak, protein, dan karbohidrat yang tinggi memiliki efek positif terhadap kelebihan berat badan di kalangan remaja. Remaja putri dengan status gizi lebih (overweight) dapat menimbulkan dysmenorrhea, karena mengkonsumsi yang berlemak dapat meningkatkan hormon prostaglandin yang dapat menyebabkan nyeri di bagian perut bawah atau dysmenorrhea dan terdapat jaringan lemak yang berlebihan yang dapat mengakibatkan hiperplasi pembuluh darah yaitu terdesaknya pembuluh darah oleh jaringan lemak pada organ reproduksi wanita sehingga darah yang seharusnya mengalir pada proses menstruasi terganggu dan menimbulkan nyeri [20]. Status gizi underweight dapat diakibatkan karena asupan makanan yang kurang, termasuk zat besi yang dapat menimbulkan anemia. Anemia merupakan salah satu faktor yang menyebabkan kurangnya daya tahan tubuh terhadap rasa nyeri sehingga pada saat menstruasi dapat terjadi dysmenorrhea primer [31].

Hasil analisis bivariat pada penelitian ini antara status gizi dengan dysmenorrhea primer di dapatkan nilai $p$-value sebesar 0,042 atau lebih kecil dari $\alpha(0,05)$ maka dapat disimpulkan bahwa terdapat hubungan antara status gizi dengan dysmenorrhea primer.

Menurut [32] status gizi merupakan bagian penting dari kesehatan seseorang. Gizi kurang selain akan mempengaruhi pertumbuhan dan fungsi organ tubuh juga akan menyebabkan terganggunya fungsi reproduksi. $\mathrm{Hal}$ ini berdampak pada gangguan haid termasuk dysmenorrhea, tetapi akan membaik bila asupan nutrisinya baik.

\section{Hubungan antara Usia Menarche dengan Dysmenorrhea Primer}

Dalam penelitian ini responden dengan usia menarche normal juga banyak yang mengalami dysmenorrhea primer. Hal ini dikarenakan asupan nutrisi yang berbeda-beda pada remaja. Remaja dengan asupan nutrisi yang baik maka usia menarche akan cepat. Sebaliknya, jika seseorang memliki gaya hidup yang tidak sehat (merokok maupun tidak pernah olahraga) maka nyeri saat menstruasi akan semakin meningkat [23].

Hasil analisis bivariat pada penelitian ini antara usia menarche dengan dysmenorrhea primer di dapatkan nilai $p$-value sebesar 0,001 atau lebih kecil dari a $(0,05)$ maka dapat disimpulkan bahwa terdapat hubungan antara usia menarche dengan dysmenorrhea primer. Menururt [33] wanita yang menarche pada usia 11 tahun atau lebih muda memiliki risiko lebih tinggi dysmenorrhea primer dibandingkan wanita dengan usia menarche lebih dari 11 tahun. 


\section{Hubungan antara Aktivitas Fisik dengan Dysmenorrhea Primer}

Remaja putri yang aktif secara fisik dysmenorrhea menurun. Remaja putri yang berolahraga sekurang-kurangnya satu kali dalam seminggu dapat menurunkan intensitas rasa nyeri dan ketidaknyamanan pada bagian bawah abdominal [34].

Hasil analisis bivariat pada penelitian ini antara aktivitas fisik dengan dysmenorrhea primer di dapatkan nilai $p$-value sebesar 0,913 atau lebih besar dari a $(0,05)$ maka dapat disimpulkan bahwa tidak terdapat hubungan antara aktivitas fisik dengan dysmenorrhea primer.

Hasil penelitian tidak ditemukan hubungan antara aktivitas fisik dengan dysmenorrhea primer, hasil ini diduga disebabkan oleh kehomogenan data dalam penelitian. Menurut [33] wanita yang tidak berolahraga 3,5 kali lebih berisiko mengalami dysmenorrhea primer dibandingkan dengan yang berolahraga.

\section{Simpulan dan Saran}

Sebagian besar usia responden yaitu 15 tahun dan sebagian besar mempunyai status gizi normal, dengan aktivitas fisik mayoritas tergolong kategori ringan, responden mayoritas mengalami dysmenorrhea primer dan mempunyai riwayat keluarga dysmenorrhea primer, responden sebagian besar memiliki lama menstruasi yang tergolong normal dan sebagian besar responden memiliki lama siklus menstruasi tergolong teratur, responden sebagian besar memiliki usia menarche tergolong normal. Berdasarkan uji statistic, terdapat hubungan antara status gizi dengan usia menarche, terdapat hubungan antara status gizi dengan dysmenorrhea primer, terdapat hubungan antara usia menarche dengan dysmenorrhea primer, tidak terdapat hubungan antara aktivitas fisik dengan dysmenorrhea primer.

. Saran yang diberikan berdasarkan hasil penelitian ini adalah siswi dianjurkan untuk menambah porsi aktivitas fisik. Tidak hanya mengandalkan jam olah raga ketika di sekolah agar status gizi siswi tetap pada kategori ideal/normal. Siswi juga disarankan untuk menjaga berat badan agar tetap pada kategori ideal/normal dengan menerapkan pola konsumsi pangan yang beragam, bergizi, seimbang dan aman. Pemberian edukasi oleh pihak sekolah terkait masalah reproduksi sejak kelas VII. Untuk penelitian selanjutnya bisa dilakukan dengan menghubungkan variabel lain dengan dysmenorrhea primer seperti anemia, stres, merokok, minuman beralkohol dll.

\section{Daftar Pustaka}

[1] Nasution D. Hubungan Status Gizi dengan Kejadian Dismenore Primer pada Remaja Putri di SMA Swasta Istiqlal Kecamatan Delitua Kabupaten Deli Serdang. 2013;00:2013.

[2] Lestari NMSD. Seminar Nasional FMIPA UNDIKSHA III. Pengaruh dismenorea pada remaja [Internet]. 2013;323-9.

Available from: ejournal.undiksha.ac.id/index.php/semn asmipa/article/download

[3] Sakinah. Faktor-faktor yang berhubungan dengan kejadian dismenorea primer pada remaja. 2016;1-65.

[4] Ammar. Faktor risiko dismenore primer pada wanita usia subur di kelurahan ploso kecamatan tambaksari surabaya. Fakt Risiko Dismenore Prim Pada Wan Usia Subur di Kelurahan Ploso KecamatanTambaksari Surabaya. 2016;4(Januari 2016):37-49.

[5] Andari R. Faktor-faktor yang Mempengaruhi Kejadian Dismenore Primer pada Remaja Putri di SMA Dharma PAncasila Medan Tahun2014. 2014;2014.

[6] Silvana PD. Hubungan antara karakteristik individu, aktivitas fisik, dan konsumsi produk susu dengan dysmenorrhea primer pada mahasiswi FIK dan FKM UI Depok tahun 2012. Skripsi Univ Indones. 2012;

[7] Rahmadhayanti E, Rohmin A. Hubungan Status Gizi dan Usia Menarche dengan Dismenorhea Primer pada Remaja Putri Kelas XI SMA Negeri $15 \quad$ Palembang. J Kesehat. 2016;7(2):255.

[8] Novia I, Puspitasari N. Faktor Risiko yang Mempengaruhi Kejadian Dismenore Primer. Indones J public Heal. 2006;4:96-103. 
Huda et al, Hubungan Status Gizi, Usia Menarche dengan Kejadian Dysmenorrhea Primer...

[9] Pratiwi H, Rodiani R. Obesitas sebagai Resiko Pemberat Dismenore pada Remaja. Med J. Lampung Univ [Internet]. 2015;4(9):108-12. Available from: http://jukeunila.com/majority/

[10] Rakhma A. Gambaran

Derajat Dismenore dan Upaya Penanganannya pada Siswi

Sekolah Menengah Kejuruan Arjuna Depok jawa Barat. 2012;5:13-5.

[11] Dinas Kesehatan Kabupaten Jember. Data Gangguan Menstruasi pada Remaja Putri. 2017.

[12] Sadiman S. Analisis Faktor yang Berhubungan dengan Kejadian Dismenorhea. J Kesehat [Internet]. 2017;8(1):41. Available from: http://ejurnal.poltekkestjk.ac.id/index.php /JK/article/view/392

[13] Sastroasmoro, S. dan Ismael S. DasarDasar Metodologi Penelitian Klinis Edisi

5. Jakarta: Sagung Seto; 2010.

[14] Notoatmodjo S. Metode

Penelitian Kesehatan. Jakarta:

Rineka Cipta; 2010.

[15] Judha et al. Teori Pengukuran Nyeri dan Nyeri Persalinan. Yogyakarta: Nuha Medika; 2012.

[16] Putri SA. Hubungan Antara Nyeri Haid ( Dismenore ) Terhadap Aktivitas Belajar pada Siswi Kelas XI SMA Negeri 52 Jakarta. Hub Antara Nyeri Haid Terhadap Akt Belajar. 2017;

[17] Tangchai et al. Dysmenorrhea in Thai adolescents: prevalence, impact and knowledge of treatment. 2004;87(3):6973. Available from: https://www.ncbi.nlm.nih.gov/pubmed/21 218593

[18] Febriana et al. Hubungan Tingkat Aktivitas Fisik Dengan Dysmenorrhea Primer Pada Remaja Umur 13-15. Jurnal. 2015;

[19] Pilliteri A. Maternal \& Child Health Nursing, Care of the Childbearing \& Childearing Family 4th Edition. Philadelphia: Lippincott William \& Wilkins; 2003.

[20] Pakaya D. Hubungan Faktor Resiko dengan Kejadian Dismenore Primer pada Siswi Kelas VIII SMPN 6 Gorontalo Tahun 2013. 2014;
[21] Kementrian Kesehatan. Standar

Antropometri Penilaian Status Gizi Anak. Standar Antropometri Penilaian Status Gizi Anak. 2010. p. 40.

[22] Wahyuni S. Hubungan Status Gizi Antropometri Dan Usia Menarche Pada Siswi Mts N Tangerang li Pamulang Tahun 2013. Fak Kedokt Univ Islam Negri Syarif Hidayatullah Jakarta. 2013;

[23] Poeverawati \& Misaroh. Menarche (Menstruasi Pertama Penuh Makna). Jakarta: Nuha Medika; 2009.

[24] Munda SS. Hubungan Antara IMT dengan Usia Menarche pada Siswi SD dan SMP di KOota Manado. 2012;150-

8.

[25] Kustin, Wahyuningtyias F, Munawir A. Health Notions, Volume 1 Issue 4 ( October-December 2017 ) ISSN 25804936 The Effects of Junk Food Consumption on Incidence of Early Puberty in Adolescent Females 408 |

Publisher: Humanistic Network for Science and Technology Health Notions , Volume 1 I. 2017;1(4):408-13.

[26] Yunitasari R. Seminar Nasional Pendidikan, Sains dan Teknologi

Fakultas Matematika dan IImu Pengetahuan Alam Universitas Muhammadiyah Semarang. Semin Nas Pendidikan, Sains dan Teknol Fak Mat dan IImu Pengetah Alam Univ Muhammadiyah Semarang. 2017;398405.

[27] Gultom P. Hubungan Status Gizi dan Aktivitas Fisik dengan Dismenore Primer pada Siswi SMA Negeri 1 Pahae Julu Tahun 2015. 2015;47.

[28] Suandi KG. Obesitas pada Remaja. Jakarta: Sagung Seto; 2004.

[29] Nugroho et al. Hubungan Antara Asupan Zat Gizi Dan Status Gizi

Dengan Kejadian Menarche Dini Pada Siswi Sd Negeri 2. Kesehatan. 2010;VI (1):36-42.

[30] Febriani RT, Soesetidjo A, Tiyas FW. Consumption of Fat, Protein, and Carbohydrate Among Adolescent with Overweight / Obesity. J Matern Child Heal. 2019;4(2):70-6. 
Huda et al, Hubungan Status Gizi, Usia Menarche dengan Kejadian Dysmenorrhea Primer...

[31] Kusmiran E. Kesehatan Reproduksi Remaja dan Wanita. Jakarta: Salemba Medika 21; 2011.

[32] Yustiana. Hubungan Status Gizi Dengan Keluhan Nyeri (Dismenore) Saat Menstruasi Pertama (Menarche) Pada Siswa SLTP Di Surakarta. 2011;
[33] Zukri et al. Primary Dysmenorrhea Among Medical And Dental University Students In Kelantan: Prevalence And Associated Factors. 2009;(March 2016).

[34] Saadah S. Hubungan Aktivitas Fisik dengan Dismenore pada Mahasiswi

Progam Studi IImu Keolahragaan. 2014; 